\title{
SYNTHESIS AND ANTIDEPRESSANT ACTIVITY OF SOME NOVEL FLUOXETINE DERIVATIVES
}

H. M. Safwat, S. E. Abbas, S. R. Mohamed, M. A. Fouad and M. M. Elmazar*

Department of Pharmaceutical Chemistry, Faculty of Pharmacy, Cairo University and $*$ British University in Egypt

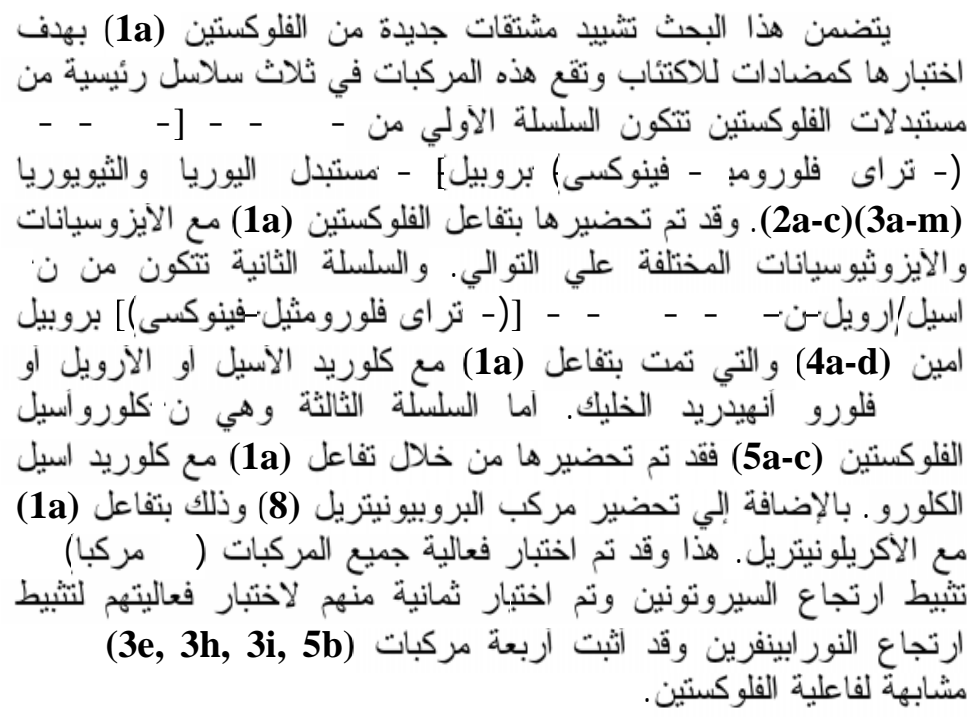

The present work involves the synthesis of three series of novel fluoxetine derivatives in order to evaluate their potential as antidepressants. The first series consists of 1-methyl-1-[3-phenyl-3(4-trifluoromethylphenoxy)propyl]-3-substituted ureas $2 a-c$ and thioureas as their bioisosters 3a-m which were prepared by reacting fluoxetine $\mathbf{1 a}$ with different isocyanates and isothiocyanates respectively. The second series $\mathrm{N}$-acyl/aroyl- $\mathrm{N}$ methyl-3-phenyl-3-(4-trifluoromethylphenoxy)-propylamines 4a-d were synthesized by refluxing $1 \mathbf{a}$ with acyl/aroyl chloride and trifluoroacetic anhydride. The third one, $N$-chloroacyl-fluoxetine $5 \boldsymbol{a}-\mathbf{c}$ was obtained via the reaction of $\mathbf{1} \boldsymbol{a}$ with chloroacyl chloride. In addition to a propionitrile derivative 8 which was achieved by

Received in 29/4/2007, Received in revised form in 9/7/2007 \& Accepted in 10/7/2007

*Present Address: The British University in Egypt, E-mail: elmazar@bue.edu.eg. 
refluxing $1 \mathbf{a}$ with acrylonitrile. The twenty four final compounds were biologically screened throughout the work for their potential as serotonin reuptake inhibitors by measuring potentiation of 5HTP induced neurotoxity and some as norepinephrine reuptake inhibitor by measuring yohimbine-induced mortality in mice to calculate5-HTP/NE ratio as a parameter for selectivity to inhibit serotonin reuptake. Four compounds $(\mathbf{3 e}, \mathbf{3 h}, \mathbf{3 i}, \mathbf{5 b})$ were found to be as potent as fluoxetine.

\section{INTRODUCTION}

Mood disorders are among the most common mental disorders encountered in clinical practice and are considered the diseases of the end of the twentieth century ${ }^{1 \& 2}$.

Depression is a complex of variable mental disorders that may be characterized by manic states as well as states of decreased motor activity. The biological etiology of depression is due to deficiency of biogenic neurotransmitters notably norepinephrine (NE) and serotonin $(5-\mathrm{HT})^{3 \& 4}$.

Antidepressants include monoamine oxidase inhibitors (MAOIs) ${ }^{5}$ tricyclic antidepressants (TCA) ${ }^{3 \& 6}$, serotonin and norepinephrine reuptake inhibitors ${ }^{4 \& 7}$, selective norepinephrine reuptake inhibitors (SNRIs) $)^{8-10}$ and selective serotonin reuptake inhibitors (SSRIs) ${ }^{4 \& 5}$. Fluoxetine 1a $( \pm)$ N-methyl-3-phenyl-3-[4-(trifluoromethyl)phenoxy] propan-

1-amine $\mathrm{HCl}$ is a selective and competitive inhibitor of serotoninreuptake $^{11}$, its selectivity for the serotonin-uptake carrier versus other monoamine-uptake carriers appears to be greater than 50 fold $^{12}$. It is still on the market since its approval ${ }^{12}$. The
(S)-enantiomer and the major metabolite norfluoxetine $\mathbf{1 b}$ are highly active against serotonin transport and also may have antimigraine effects not found in the (R)- enantiomer ${ }^{4}$. Moreover, fluoxetine1a has a delay in the onset of action for about 2-6 weeks, although it shows reduced side effects compared to other antidepressant $\operatorname{drugs}^{11,13}$.<smiles>[R]NCCC(Oc1ccc(C(F)(F)F)cc1)c1ccccc1</smiles>

(1)
a) $\mathrm{R}=\mathrm{CH}_{3}$
b) $\mathrm{R}=\mathrm{H}$

Literature survey declared the preparation procedure for some $\mathrm{N}$ substituted derivatives of N-methyl-3(4-trifluoromethylphenoxy)-3-phenylpropylamine having the general formula (A) through the reaction with chloroformic acid esters, where $\mathrm{n}=1$, $\mathrm{R}=$ alkyl, alkylaryl and aryl groups. Also, other $\mathrm{N}$-substituted derivatives of (A) are included where $\mathrm{n}=0, \mathrm{R}=$ alkyl and alkylaryl ${ }^{14}$. 


$$
\text { (A) }
$$

As most (SSRIs) are aryl or aryloxyamines, the phenoxyphenylpropanamine skeleton appears to be a suitable framework for preparation of a variety of substituted fluoxetine and screening their antidepressant activity $^{14}$. Therefore, we are interested to substitute the (COO)n R side chain of (A) by different isosteric moieties including CONHR and CSNHR, where $\mathrm{R}=$ alkyl, aryl and alkylaryl to obtain novel Nsubstituted fluoxetine derivatives 2a-c and 3a-m. Further N-substitution is achieved using acid chloride, chloroacyl chloride or trifluoroacetic anhydride to give $\mathbf{4 a - c ,} \mathbf{5 a - c}$ or $\mathbf{4 d}$ respectively. In addition, a cyanoethyl derivative $\mathbf{8}$ is performed in order to investigate the influence of the $\mathrm{N}$ substitution of fluoxetine on its antidepressant activity.

\section{EXPERIMENTAL}

\section{Chemistry}

Melting points were uncorrected and were determined by open capillary tube method using Electrothermal 9100 digital melting point apparatus. Elemental microanalyses were carried out at the microanalytical centre, Faculty of Science, Cairo University. Infrared spectra were recorded on JASCO FT/IR-460Plus spectrophotometer and Bruker FT-IR spectrophotometer Vector 22 as potassium bromide discs or neat. ${ }^{1} \mathrm{H}$ NMR were recorded on Varian Gemini 200 spectrophotometer at $200 \mathrm{MHz}$, using TMS as internal standard and Varian Mercury spectrophotometer at $300 \mathrm{MHz}$. Chemical shift values ( $\delta$ ) are given in (ppm). Mass spectra were performed on Schimadzu GCMS-QP1000EX mass spectrophotometer, Hewlett Packard 5988A GC/MS mass spectrophotometer, and Fennigan MAT, SSQ 7000 GC/MS mass spectrophotometer at $70 \mathrm{eV}$. Reaction time was determined by TLC using Macherey-Nagel Alugram Sil $\mathrm{G} / \mathrm{UV}_{254}$ silica gel plates with fluorescent indicator $\mathrm{UV}_{254}$, and carbon tetrachloride: methanol $(9.5$ : 0.5 ) as the eluting system and the spots were visualized using Vilber Lourmet ultraviolet lamp at $\lambda=$ $254 \mathrm{~nm}$.

1-Methyl-1-[3-phenyl-3-(4-trifluoromethylphenoxy)-propyl]-3substituted ureas 2a-c

A mixture of fluoxetine base $(0.45$ $\mathrm{g} ; 1.45 \mathrm{mmol})$, the appropriate isocyanate $(1.59 \mathrm{mmol})$ and triethylamine $(0.15 \mathrm{~g}, 1.45 \mathrm{mmol})$ in dry benzene $(20 \mathrm{ml})$ was refluxed for 10-15 hours. The solvent was evaporated under reduced pressure and the residue was recrystallized from absolute ethanol. Table 1. 2a: IR $(\mathrm{KBr}) 3327(\mathrm{NH})$ and $1626(\mathrm{CO}) .2 \mathbf{b}$ : 
(KBr) $3346(\mathrm{NH})$ and $1645(\mathrm{CO}) .2 \mathrm{c}$ : (KBr) $3295(\mathrm{NH})$ and $1632(\mathrm{CO}) . \mathbf{2 b}$ : ${ }^{1} \mathrm{H}$ NMR $\left(\mathrm{CDCl}_{3}\right) \delta=2.18(\mathrm{q}, 2 \mathrm{H}$ at $\mathrm{C}_{2}$ of the propanamine), $3.04(\mathrm{~s}, 3 \mathrm{H}$, $\left.\mathrm{NCH}_{3}\right), \quad 3.59 \quad\left(\mathrm{~m}, 2 \mathrm{H}\right.$ at $\mathrm{C}_{1}$ of the propanamine), $5.27\left(\mathrm{t}, 1 \mathrm{H}\right.$ at $\mathrm{C}_{3}$ of the propanamine), $7.25(\mathrm{~m}, 14 \mathrm{H}$, aromatic protons), 8.92 (s, $1 \mathrm{H}$ of $\left.\mathrm{NHCOC}_{6} \mathrm{H}_{5}\right)$. 2a: Ms: $\mathrm{m} / \mathrm{z}(\%)=\mathrm{M}^{+} 434(13.30)$ and 273 (100). 2b: Ms: $\mathrm{m} / \mathrm{z}(\%)=\mathrm{M}^{+} 428$ (11.68) and 267 (100). 2c: Ms: m/z $(\%)=\mathrm{M}^{+} 462$ (8.22) and $197(100)$.

1-Methyl-1-[3-phenyl-3-(4-trifluoromethylphenoxy)-propyl]-3substituted thioureas 3a-m

A mixture of fluoxetine base $(0.45$ $\mathrm{g}, \quad 1.45 \mathrm{mmol}$ ), the appropriate isothiocyanate $(1.59 \mathrm{mmol})$ and triethylamine $(0.15 \mathrm{~g}, 1.45 \mathrm{mmol})$ in absolute ethanol $(20 \mathrm{ml})$ was refluxed for 24 hours. The solvent was evaporated under reduced pressure and the residue was recrystallized from absolute ethanol or purified by flash chromatography using alumina gel as the stationary phase and chloroform: methanol $(9.5: 0.5)$ as the mobile phase. Table1, 3a: IR ( $\mathrm{KBr})$ $3362(\mathrm{NH})$ and 3e: $\mathrm{IR}(\mathrm{KBr}) 3216$ (NH). 3a: ${ }^{1} \mathrm{H}$ NMR (DMSO) $\delta=2.17$ (m, $2 \mathrm{H}$ at $\mathrm{C}_{2}$ propanamine), $2.89(\mathrm{~d}$, $\left.3 \mathrm{H}, \mathrm{CH}_{3} \quad \mathrm{CSNHCH}_{3}\right), 3.04 \quad(\mathrm{~s}, 3 \mathrm{H}$, $\left.\mathrm{NCH}_{3}\right), \quad 3.95 \quad\left(\mathrm{~m}, \quad 2 \mathrm{H}\right.$ at $\mathrm{C}_{1}$ propanamine), $5.49 \quad\left(\mathrm{t}, 1 \mathrm{H}\right.$ at $\mathrm{C}_{3}$ propanamine), $7.39(\mathrm{~m}, \quad 10 \mathrm{H}$, aromatic and $\mathrm{NH}$ protons). $\mathbf{3 c}$ : ${ }^{1} \mathrm{HNMR}\left(\mathrm{CDCl}_{3}\right) \delta=2.25$ (q, $2 \mathrm{H}$ at $\left.\mathrm{C}_{2}\right), 3.04\left(\mathrm{~s}, 3 \mathrm{H}, \mathrm{NCH}_{3}\right), 3.94$ (t, $2 \mathrm{H}$ at $\left.\mathrm{C}_{1}\right), 4.20\left(\mathrm{~m}, 2 \mathrm{H}\right.$ at $\mathrm{C}_{1}$ allyl), 5.05 (d, $2 \mathrm{H} \mathrm{C}_{3}$ allyl), $5.25\left(\mathrm{t}, 1 \mathrm{H}\right.$ at $\mathrm{C}_{3}$ ), $5.75\left(\mathrm{~m}, 1 \mathrm{H}\right.$ at $\mathrm{C}_{2}$ allyl), $7.29(\mathrm{~m}, 9 \mathrm{H}$, aromatic protons) and $11.51(\mathrm{~s}, 1 \mathrm{H}$, NHCSNallyl). 3f: ${ }^{1} \mathrm{H}$ NMR $\left(\mathrm{CDCl}_{3}\right)$ $\delta=2.34\left(\mathrm{q}, 2 \mathrm{H}\right.$ at $\left.\mathrm{C}_{2}\right), 3.28(\mathrm{~s}, 3 \mathrm{H}$, $\left.\mathrm{NCH}_{3}\right), 4.04\left(\mathrm{~m}, 2 \mathrm{H}\right.$ at $\left.\mathrm{C}_{1}\right), 5.33(\mathrm{t}, 1 \mathrm{H}$ at $\left.\mathrm{C}_{3}\right), 7.25(\mathrm{~m}, 14 \mathrm{H}$, aromatic protons and $\mathrm{NH}$ proton). 3a: Ms: $\mathrm{m} / \mathrm{z}$ $(\%)=\mathrm{M}^{+} 382(25.28)$ and $117(100)$. 3c: $\mathrm{Ms}: \mathrm{m} / \mathrm{z}(\%)=\mathrm{M}^{+} 408(26.78)$ and (100). 3e: Ms: $\mathrm{m} / \mathrm{z}(\%)=\mathrm{M}^{+} 445$ (7.14) and 91 (100) and 3f: Ms: m/z $(\%)=\mathrm{M}^{+} 478$ (21.6) and (100).

\section{N-Methyl-N-[3-phenyl-3-(4-tri- fluoromethylphenoxy)propyl]- cyclohexanecarboxamide $4 \mathrm{a}, \quad \mathrm{N}$ - Methyl-N-[3-phenyl-3-(4-trifluoro- methylphenoxy)-propyl]-4- chlorobenzamide $4 \mathrm{c}$}

A mixture of the corresponding carboxylic acid $(1.45 \mathrm{mmol})$ and thionyl chloride $(0.17 \mathrm{~g}, 1.45 \mathrm{mmol})$ in dry benzene $(10 \mathrm{ml})$ was refluxed for 3 hours. Fluoxetine base $(0.45 \mathrm{~g}$, $1.45 \mathrm{mmol}$ ) and anhydrous potassium carbonate $(0.20 \mathrm{~g}, 1.45 \mathrm{mmol})$ were added and reflux was continued for additional 6 hours. The mixture was filtered while hot, and the solvent was evaporated under reduced pressure. The residue was solidified by trituration with petroleum ether (40$60^{\circ} \mathrm{C}$ ) and recrystallized from ethanol. Table 2. 4a: IR (KBr) $1627(\mathrm{CO})$ and 4c: IR (KBr) 1620 (CO). 4a: ${ }^{1} \mathrm{H}$ NMR $\left(\mathrm{CDCl}_{3}\right) \delta=1.50(\mathrm{~m}, 11 \mathrm{H}$, cyclohexyl protons), 2.07 (q, $2 \mathrm{H}$ at $\mathrm{C}_{2}$ ), 2.95 (d, $\left.3 \mathrm{H}, \mathrm{NCH}_{3}\right), 3.48\left(\mathrm{~m}, 2 \mathrm{H}\right.$ at $\left.\mathrm{C}_{1}\right)$, $5.17\left(\mathrm{t}, 1 \mathrm{H}\right.$ at $\left.\mathrm{C}_{3}\right), 7.29(\mathrm{~m}, 9 \mathrm{H}$, aromatic protons). 


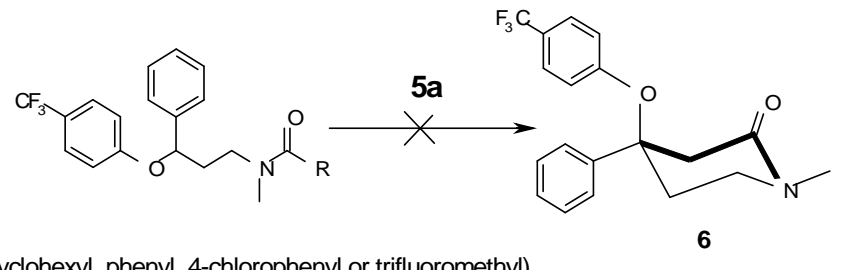

4a-d $\mathrm{R}=$ cyclohexyl, phenyl, 4-chlorophenyl or trifluoromethyl) 5a-c $\mathrm{R}=$ chloromethyl, 1-chloroethyl, 2-chloroethyl

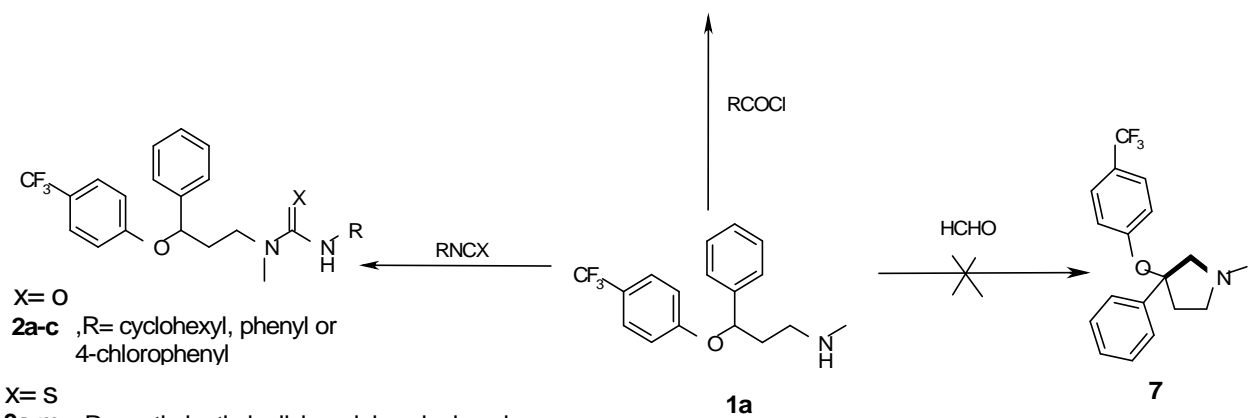

3a-m , R= methyl, ethyl, allyl, cyclohexyl, phenyl, 4-chlorophenyl, 2-chlorophenyl,4-bromophenyl, 2-bromophenyl, 4-methyl phenyl,

2-methylphenyl, 3-methylphenyl or 4-carboxyphenyl)

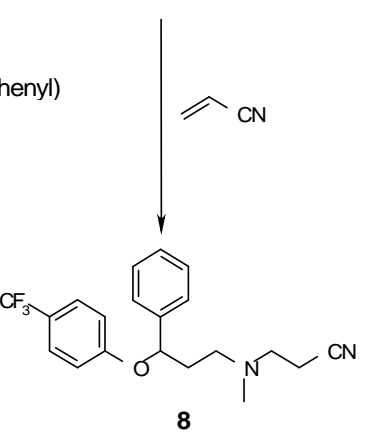

Scheme

67 
<smiles>[R]NC([X])N(C)CCC(Oc1ccc(C(F)(F)F)cc1)c1ccccc1</smiles>

Table 1: Physical and analytical data of the prepared compounds 2a-c and 3a-m.

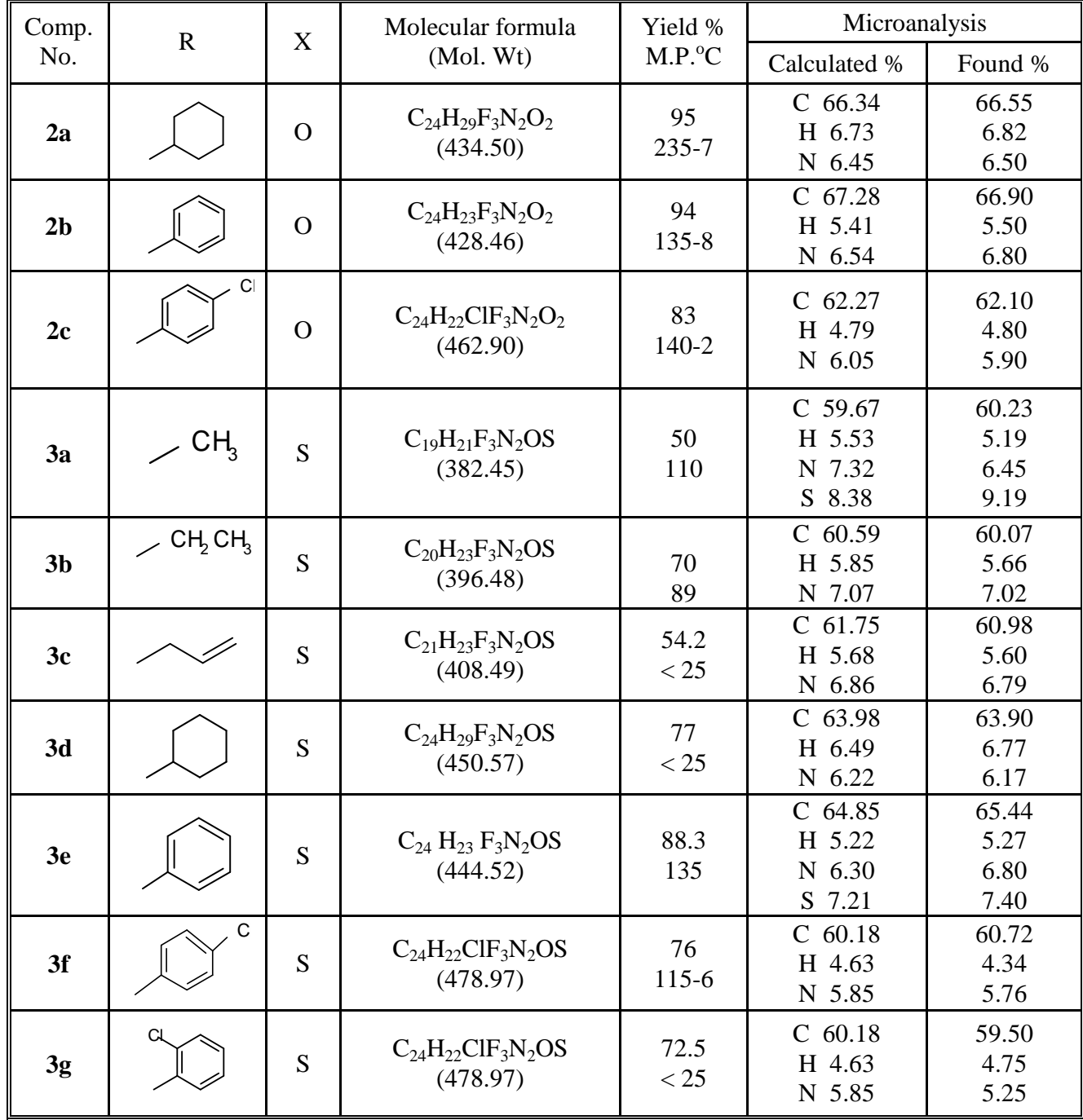


Table 1: Continue

\begin{tabular}{|c|c|c|c|c|c|c|}
\hline \multirow{2}{*}{$\begin{array}{l}\text { Comp. } \\
\text { No. }\end{array}$} & \multirow{2}{*}{$\mathrm{R}$} & \multirow{2}{*}{$X$} & \multirow{2}{*}{$\begin{array}{l}\text { Molecular formula } \\
\quad \text { (Mol. Wt) }\end{array}$} & \multirow{2}{*}{$\begin{array}{l}\text { Yield \% } \\
\text { M.P. }{ }^{\circ} \mathrm{C}\end{array}$} & \multicolumn{2}{|c|}{ Microanalysis } \\
\hline & & & & & Calculated \% & Found $\%$ \\
\hline $3 h$ & & S & $\begin{array}{c}\mathrm{C}_{24} \mathrm{H}_{22} \mathrm{BrF}_{3} \mathrm{~N}_{2} \mathrm{OS} \\
(522.42)\end{array}$ & $\begin{array}{c}86.7 \\
125-6\end{array}$ & $\begin{array}{c}\text { C } 55.17 \\
\text { H } 4.21 \\
\text { N } 5.35 \\
\end{array}$ & $\begin{array}{c}55.67 \\
4.54 \\
5.20 \\
\end{array}$ \\
\hline $3 \mathbf{i}$ & & $S$ & $\begin{array}{c}\mathrm{C}_{24} \mathrm{H}_{22} \mathrm{BrF}_{3} \mathrm{~N}_{2} \mathrm{OS} \\
(522.42)\end{array}$ & $\begin{array}{c}38 \\
85-90\end{array}$ & $\begin{array}{cc}\text { C } 55.07 \\
\mathrm{H} 4.24 \\
\mathrm{~N} 5.35 \\
\end{array}$ & $\begin{array}{c}55.41 \\
4.57 \\
5.24 \\
\end{array}$ \\
\hline $\mathbf{3 j}$ & & S & $\begin{array}{c}\mathrm{C}_{25} \mathrm{H}_{25} \mathrm{~F}_{3} \mathrm{~N}_{2} \mathrm{OS} \\
(458.55)\end{array}$ & $\begin{array}{c}54 \\
105-7\end{array}$ & $\begin{array}{cc}\mathrm{C} & 65.48 \\
\mathrm{H} & 5.50 \\
\mathrm{~N} & 6.11 \\
\end{array}$ & $\begin{array}{c}66.18 \\
5.52 \\
6.12 \\
\end{array}$ \\
\hline $3 \mathbf{k}$ & & $S$ & $\begin{array}{c}\mathrm{C}_{25} \mathrm{H}_{25} \mathrm{~F}_{3} \mathrm{~N}_{2} \mathrm{OS} \\
(458.55)\end{array}$ & $\begin{array}{c}36 \\
128-32\end{array}$ & $\begin{array}{cc}\text { C } & 65.48 \\
\mathrm{H} & 5.50 \\
\mathrm{~N} & 6.11\end{array}$ & $\begin{array}{c}64.87 \\
6.00 \\
6.02\end{array}$ \\
\hline 31 & & $S$ & $\begin{array}{c}\mathrm{C}_{25} \mathrm{H}_{25} \mathrm{~F}_{3} \mathrm{~N}_{2} \mathrm{OS} \\
(458.55)\end{array}$ & $\begin{array}{c}99 \\
55-60\end{array}$ & $\begin{array}{cc}\text { C } & 65.48 \\
\text { H } & 5.50 \\
N & 6.11\end{array}$ & $\begin{array}{c}66.14 \\
4.75 \\
5.95\end{array}$ \\
\hline $3 m$ & & $S$ & $\begin{array}{c}\mathrm{C}_{25} \mathrm{H}_{23} \mathrm{~F}_{3} \mathrm{~N}_{2} \mathrm{O}_{3} \mathrm{~S} \\
(488.53)\end{array}$ & $\begin{array}{c}57.5 \\
150-3\end{array}$ & $\begin{array}{cc}\mathrm{C} & 61.47 \\
\mathrm{H} & 4.75 \\
\mathrm{~N} & 5.73\end{array}$ & $\begin{array}{l}61.08 \\
4.72 \\
5.63\end{array}$ \\
\hline
\end{tabular}

\section{N-Methyl-N-[3-phenyl-3-(4-tri- fluoromethylphenoxy)propyl]benz- amide 4b}

A mixture of sodium hydroxide $(0.10 \mathrm{~g}, 2.60 \mathrm{mmol})$, fluoxetine base $(0.62 \mathrm{~g}, 2.00 \mathrm{mmol})$ and water $(10$ ml) was treated with benzoyl chloride $(0.28 \mathrm{~g}, 2.00 \mathrm{mmol})$ with continuous stirring during the course of one hour, keeping the temperature down by cooling with running water. The reaction mixture was extracted with benzene. The organic phase was dried over anhydrous magnesium sulphate and the solvent was evaporated under reduced pressure. The residue was purified by flash chromatography using alumina gel as the stationary phase and carbon tetrachloride: methanol (9.8:0.2) as the mobile phase and separated as oily product. Table 2. IR (KBr) $1715.0(\mathrm{CO}) .{ }^{1} \mathrm{H}$ NMR $\left(\mathrm{CDCl}_{3}\right): \delta=2.24$ (q, $2 \mathrm{H}$ at $\left.\mathrm{C}_{2}\right)$, $3.08\left(\mathrm{~d}, 3 \mathrm{H}, \mathrm{NCH}_{3}\right), 3.78(\mathrm{~m}, 2 \mathrm{H}$ at $\left.\mathrm{C}_{1}\right), 5.36\left(\mathrm{t}, 1 \mathrm{H}\right.$, at $\left.\mathrm{C}_{3}\right)$ and $7.05(\mathrm{~m}$, $14 \mathrm{H}$, aromatic protons).

\section{N-Methyl-N-[3-phenyl-3-(4-trifluo- romethylphenoxy)propyl]-2,2,2- trifluoroacetamide $\mathbf{4 d}$}

A mixture of fluoxetine base $(0.53$ $\mathrm{g}, \quad 1.70 \mathrm{mmol}), \quad$ trifluoroacetic anhydride $(0.36 \mathrm{~g}, 1.70 \mathrm{mmol})$ and triethylamine $(0.17 \mathrm{~g}, 1.70 \mathrm{mmol})$ in dry benzene $(20 \mathrm{ml})$ was stirred at 0 $5^{\circ} \mathrm{C}$ for 2 hours, then at room temperature for 24 hours. The reaction mixture was poured onto ice; the oil separated was extracted with $2 \times 10 \mathrm{ml}$ chloroform. The organic 
phase was washed with $3 \times 10 \mathrm{ml}$ brine solution, dried over anhydrous magnesium sulphate and the solvent was evaporated under reduced pressure. The residue was purified by flash chromatography using alumina gel as the stationary phase and carbon tetrachloride: methanol $(9.5: 0.5)$ as the mobile phase and separated as oily product. Table 2 . IR ( $\mathrm{KBr})$ $1695.8(\mathrm{CO}) .{ }^{1} \mathrm{H} \mathrm{NMR}\left(\mathrm{CDCl}_{3}\right): \delta=$ $2.23\left(\mathrm{~m}, 2 \mathrm{H}\right.$ at $\left.\mathrm{C}_{2}\right), 3.07(\mathrm{~d}, 3 \mathrm{H}$, $\left.\mathrm{NCH}_{3}\right), 3.64\left(\mathrm{t}, 2 \mathrm{H}\right.$ at $\left.\mathrm{C}_{1}\right), 5.320(\mathrm{t}, 1 \mathrm{H}$, at $\left.\mathrm{C}_{3}\right)$ and $7.15(\mathrm{~m}, 9 \mathrm{H}$, aromatic protons). Ms: $\mathrm{m} / \mathrm{z} \quad(\%)=\mathrm{M}^{+} 405$ $(0.10)$ and 140 (100).<smiles>CC(=O)N(C)CCC(Oc1ccc(C(F)(F)F)cc1)c1ccccc1</smiles>

Table 2: Physical and analytical data of the prepared compounds 4a-5c.

\begin{tabular}{|c|c|c|c|c|c|}
\hline \multirow{2}{*}{$\begin{array}{l}\text { Comp. } \\
\text { No. }\end{array}$} & \multirow{2}{*}{$\mathrm{R}$} & \multirow{2}{*}{$\begin{array}{l}\text { Molecular formula } \\
\text { (Mol. Wt) }\end{array}$} & \multirow{2}{*}{$\begin{array}{l}\text { Yield \% } \\
\text { M.P. }{ }^{\circ} \mathrm{C}\end{array}$} & \multicolumn{2}{|c|}{ Microanalysis } \\
\hline & & & & Calculated $\%$ & Found $\%$ \\
\hline $4 a$ & & $\begin{array}{c}\mathrm{C}_{24} \mathrm{H}_{28} \mathrm{~F}_{3} \mathrm{NO}_{2} \\
(419.49)\end{array}$ & $\begin{array}{c}68.5 \\
80-83\end{array}$ & $\begin{array}{cc}\mathrm{C} & 68.72 \\
\mathrm{H} & 6.73 \\
\mathrm{~N} & 3.34\end{array}$ & $\begin{array}{c}69.20 \\
6.80 \\
3.05\end{array}$ \\
\hline $4 b$ & & $\begin{array}{c}\mathrm{C}_{24} \mathrm{H}_{22} \mathrm{~F}_{3} \mathrm{NO}_{2} \\
\quad(413.44)\end{array}$ & $\begin{array}{c}62 \\
\text { Oil at RT }\end{array}$ & $\begin{array}{c}\text { C } 69.72 \\
\text { H } 5.36 \\
\text { N } 3.39\end{array}$ & $\begin{array}{c}69.30 \\
5.30 \\
3.31\end{array}$ \\
\hline $4 c$ & & $\begin{array}{c}\mathrm{C}_{24} \mathrm{H}_{21} \mathrm{ClF}_{3} \mathrm{NO}_{2} \\
(447.89)\end{array}$ & $\begin{array}{c}60.5 \\
80-82\end{array}$ & $\begin{array}{cc}C & 64.36 \\
H & 4.73 \\
N & 3.13\end{array}$ & $\begin{array}{c}64.54 \\
4.92 \\
3.07\end{array}$ \\
\hline 4d & & $\begin{array}{c}\mathrm{C}_{19} \mathrm{H}_{17} \mathrm{~F}_{6} \mathrm{NO}_{2} \\
\quad(405.34)\end{array}$ & $\begin{array}{c}45 \\
\text { Oil at RT }\end{array}$ & $\begin{array}{cc}\text { C } & 56.30 \\
\text { H } & 4.23 \\
\text { N } & 3.46\end{array}$ & $\begin{array}{c}56.87 \\
5.21 \\
3.35\end{array}$ \\
\hline $5 \mathbf{a}$ & & $\begin{array}{c}\mathrm{C}_{19} \mathrm{H}_{19} \mathrm{ClF}_{3} \mathrm{NO}_{2} \\
(385.81)\end{array}$ & $\begin{array}{c}68 \\
63-5\end{array}$ & $\begin{array}{ll}\text { C } & 59.15 \\
\text { H } & 4.96 \\
N & 3.63 \\
\text { Cl } & 9.20\end{array}$ & $\begin{array}{c}58.32 \\
5.00 \\
3.62 \\
9.50\end{array}$ \\
\hline $5 b$ & & $\begin{array}{c}\mathrm{C}_{20} \mathrm{H}_{21} \mathrm{ClF}_{3} \mathrm{NO}_{2} \\
(399.84)\end{array}$ & $\begin{array}{l}71.5 \\
60-1\end{array}$ & $\begin{array}{cc}\text { C } & 60.08 \\
\mathrm{H} & 5.29 \\
\mathrm{~N} & 3.50 \\
\mathrm{Cl} & 8.87 \\
\end{array}$ & $\begin{array}{c}60.20 \\
6.00 \\
3.77 \\
8.40 \\
\end{array}$ \\
\hline $5 c$ & & $\begin{array}{c}\mathrm{C}_{20} \mathrm{H}_{21} \mathrm{ClF}_{3} \mathrm{NO}_{2} \\
(399.84)\end{array}$ & $\begin{array}{c}69 \\
77-9\end{array}$ & $\begin{array}{cc}\text { C } & 60.08 \\
\text { H } & 5.29 \\
N & 3.50 \\
\text { Cl } & 8.87\end{array}$ & $\begin{array}{c}59.83 \\
5.70 \\
3.55 \\
8.63\end{array}$ \\
\hline
\end{tabular}




\section{N-methyl-N-[3-phenyl-3-(4-tri- \\ fluoromethylphenoxy)propyl]chlor oacylamides 5a-c}

A mixture of fluoxetine $\mathrm{HCl}(0.50$ $\mathrm{g}, \quad 1.45 \mathrm{mmol}$ ), the appropriate chloroacyl chloride $(1.595 \mathrm{mmol})$ and anhydrous potassium carbonate $(0.40$ $\mathrm{g}, 2.90 \mathrm{mmol}$ ) in dry benzene, was refluxed for 6-24 hours. The hot solution was filtered, the solvent was evaporated under reduced pressure and the residue was recrystallized from absolute ethanol. Table 2. 5a: IR (KBr) 1657 (CO). 5b: IR (KBr) 1648 (CO). 5c: IR (KBr) 1643 (CO). 5a: ${ }^{1} \mathrm{H}$ NMR $\left(\mathrm{CDCl}_{3}\right): \delta=2.20(\mathrm{~m}, 2 \mathrm{H}$ at $\mathrm{C}_{2}$ ), 3.00(d, $\left.3 \mathrm{H}, \mathrm{NCH}_{3}\right), 3.59$ (t, $2 \mathrm{H}$ at $\left.\mathrm{C}_{1}\right), 4.00\left(\mathrm{~s}, 2 \mathrm{H}, \mathrm{COCH}_{2} \mathrm{Cl}\right), 5.20(\mathrm{t}, 1 \mathrm{H}$ at $\left.\mathrm{C}_{3}\right), 7.30(\mathrm{~m}, 9 \mathrm{H}$, aromatic protons). 5a: Ms: $\mathrm{m} / \mathrm{z}(\%)=\mathrm{M}^{+} 386(0.07)$ and 121(100). 5b: Ms: m/z (\%)= $\mathrm{M}^{+} 399$ (0.3) and 134 (100) and 5c: Ms: m/z $(\%)=\mathrm{M}^{+} 399(0.60)$ and $238(100)$.

\section{3-\{Methyl-[3-phenyl-3-(4-trifluo- romethylphenoxy)propyl]amino\}pr opionitrile 8 \\ A mixture of fluoxetine base $(0.62$} $\mathrm{g}, 2.00 \mathrm{mmol})$, acrylonitrile $(0.14 \mathrm{ml}$, $2.00 \mathrm{mmol})$ in dry benzene $(10 \mathrm{ml})$ was refluxed for 24 hours. The solvent was evaporated under reduced pressure and the residue was purified by flash chromatography using alumina gel as the stationary phase and chloroform as the mobile phase to give compound 8 . (Yield $=55 \%$, m.p. $=$ Oil at room temperature). Microanalysis for $\mathrm{C}_{20} \mathrm{H}_{21} \mathrm{~F}_{3} \mathrm{~N}_{2} \mathrm{O}$ Calculated (\%)C: 66.29; H: 5.80; N: 7.73. Found (\%)C: $65.55 ; \mathrm{H}: 5.80 ; \mathrm{N}$ : 7.62. IR (KBr) $2247.9(\mathrm{CN}) .{ }^{1} \mathrm{H}$ NMR
$\left(\mathrm{CDCl}_{3}\right): \quad \delta=1.96 \quad(\mathrm{~m}, \quad 2 \mathrm{H}$

$\left.\mathrm{CH}_{2} \mathrm{CH}_{2} \mathrm{CN}\right), \quad 2.15 \quad(\mathrm{t}, \quad 2 \mathrm{H}$, $\left.\mathrm{CH}_{2} \mathrm{CH}_{2} \mathrm{CN}\right), \quad 2.25\left(\mathrm{~s}, \quad 3 \mathrm{H}, \quad \mathrm{NCH}_{3}\right)$, $2.38\left(\mathrm{t}, 2 \mathrm{H}\right.$ at $\left.\mathrm{C}_{1}\right), 2.64\left(\mathrm{~m}, 2 \mathrm{H}\right.$ at $\left.\mathrm{C}_{2}\right)$, 5.41( $\mathrm{t}, 1 \mathrm{H}$ at $\left.\mathrm{C}_{3}\right), 7.15(\mathrm{~m}, 9 \mathrm{H}$, aromatic protons). Ms: $\mathrm{m} / \mathrm{z} \quad(\%)=\mathrm{M}^{+} 362$ (0.10) and 97 (100).

\section{Antidepressant activity}

All the twenty four newly synthesized compounds were studied for their serotonin-reuptake inhibition by measuring potentiation of 5-HTP (5-hydroxytryptophan) induced neurotoxicity in mice. Eight compounds $2 \mathbf{a}, \mathbf{2 b}, \mathbf{2 c}, \mathbf{3 e}, \mathbf{3 h}, \mathbf{3 i}, \mathbf{5 a}$ and $\mathbf{5 b}$ were tested for their norepinephrine-reuptake inhibition by measuring yohimbine-induced mortality to calculate 5-HT/NE ratio as a parameter for selectivity to inhibit serotonin reuptake. These compounds were chosen on the basis of the steep 5-HTP-induced neurotoxicity curve, except compounds $\mathbf{2 a}, \mathbf{2 c}$ and $\mathbf{5 a}$ which were included in this study although they showed less effect in the 5-HTP model in order to obtain a correlation about the SAR of these derivatives.

Potentiation of 5-HTP- induced neurotoxicity in mice in vivo ${ }^{15}$

Two control groups, six animals each, were used; one handeled alcohol-water as a solvent system, while the other used water-tween as a suspending agent. Three doses of each compound were administered to three groups (six animals each). Animals were injected i.p. with the compound or the vehicle. Thirty 
minutes later, the mice received 75 $\mathrm{mg} / \mathrm{kg}$ pargyline $\mathrm{HCl}$ s.c. in a loose fold of skin on the back of the neck. Ninety minutes after pargyline, the animals were injected with 5-HTP, (5 $\mathrm{mg} / \mathrm{kg}$, i.p.). The number of animals with head-shakes (neurotoxicity) is recorded for each group within 20 minutes. From the dose-response curve: The median toxic dose $\left(\mathrm{TD}_{50}\right)$ is calculated for each compound as well as its $95 \%$ confidence limit using the method of Litchfield and Wilcoxon ${ }^{16}$.

\section{Potentiation of yohimbine induced mortality $^{17}$}

A general control group was used for water-tween as a suspending agent, consisting of six animals. Three to five doses of each compound were administered to each animal of each group, each group comprises six animals. In case of fluoxetine, a doseyohimbine mortality curve could not be established experimentally. Male mice $(22-25 \mathrm{~g})$ are randomly assigned to test groups. The compound or vehicle is given i.p. thirty minutes prior to s.c. injection of $25 \mathrm{mg} / \mathrm{kg}$ yohimbine (a sublethal dose). The groups are placed into cages with free access of food and water. The number of animals died within 24 hours is recorded for each group. From the dose-mortality curve, the median lethal dose $\left(\mathrm{LD}_{50}\right)$ is calculated for each compound as well as its $95 \%$ confidence limit using the method of Litchfield and Wilcoxon ${ }^{16}$.

\section{5-HT/NE selectivity ratio}

The selectivity in inhibiting the reuptake of 5-HT and NE by using 5HTP induced neurotoxicity and yohimbine induced mortality as a ratio of $\mathrm{TD}_{50}$ from 5-HTP model to the $\mathrm{YLD}_{50}$ of yohimbine model as $\mathrm{mM}$ is calculated and compared with that of fluoxetine and clomipramine.

\section{RESULTS AND DISCUSSION}

\section{Chemistry}

Fluoxetine 1a was refluxed with isocyanates / isothiocyanates in presence of triethylamine to give the corresponding ureas 2a-c and thioureas 3a-m respectively. IR spectra of compound $\mathbf{2 b}$ revealed the appearance of a band corresponding to $(\mathrm{CO})$ at $1645 \mathrm{~cm}^{-1}$, in addition to the $(\mathrm{NH})$ band at $3346 \mathrm{~cm}^{-1} .{ }^{1} \mathrm{H}$ NMR of $\mathbf{2 b}$ showed an increase in the integration of aromatic protons (9 to $14 \mathrm{Hs})$ at $7.25 \mathrm{ppm}$ and mass spectrum was in accordance with the structure.

Furthermore, refluxing 1a with cyclohexanoyl or p-chlorobenzoyl chloride in dry benzene and in presence of anhydrous potassium carbonate afforded the amide derivatives $\mathbf{4 a}$ and $\mathbf{4 c}$. The benzamide 4b was prepared through reacting 1a with benzoyl chloride on cold in aqueous sodium hydroxide. Preparation of the trifluoroacetamide 4d was done by stirring 1a with trifluoroacetic anhydride at $0-5^{\circ} \mathrm{C}$ then at room temperature. IR of the amide derivatives 4a-d revealed the lack of $(\mathrm{NH})$ band and the appearance 
of the (CO) band at $\approx 1620 \mathrm{~cm}-1 .{ }^{1} \mathrm{H}$ NMR of $4 \mathbf{a}$ showed multiplet at 1.50 $\mathrm{ppm}$ assigned to $(11 \mathrm{Hs})$ of the cyclohexyl. ${ }^{1} \mathrm{H} \quad \mathrm{NMR}$ of $4 \mathrm{~b}$ demonstrated an increase in the integration of aromatic protons at $7.05 \mathrm{ppm}$ attributed to (m, $14 \mathrm{Hs})$.

Moreover, N-chloroacyl derivatives $\mathbf{5 a}$-c were achieved by refluxing 1a with the appropriate choroacyl chloride in dry benzene and in presence of anhydrous potassium carbonate. IR spectrum of $\mathbf{5 a}$ revealed the disappearance of $(\mathrm{NH})$ band and the appearance of a new band at 1657 $\mathrm{cm}^{-1}$ corresponding to (CO). ${ }^{1} \mathrm{H}$ NMR spectrum of 5 a showed a new singlet at $4.00 \mathrm{ppm}(2 \mathrm{Hs})$ assigned to the methylene protons of the chloroacetyl moiety. Mass spectra of $\mathbf{5 a - c}$ were complying with their structures.

Many attempts were carried out to cyclize 5a into a six membered ring (piperidin-2-one derivative) 6 using different bases. All trials failed to give the target compound 6 and ${ }^{1} \mathrm{H}$ NMR revealed the presence of the characteristic signal of the benzylic proton at $5.30 \mathrm{ppm}$. Another attempt was done to rigidify fluoxetine by locking free rotation of the propanamine chain in a five membered ring $\mathbf{7}$ (a pyrrolidine derivative). The trial was carried out by refluxing 1a with $35 \%$ formaldehyde solution but unfortunately fluoxetine was recovered unchanged.
Further modification of fluoxetine nucleus was done by refluxing $\mathbf{1 a}$ with acrylonitrile in dry benzene. IR of the obtained propionitrile derivative 8 showed a strong and sharp nitrile stretching band at 2247 $\mathrm{cm}^{-1}$ in addition to the disappearance of the (NH) band. ${ }^{1} \mathrm{H}$ NMR showed two new signals: a multiplet at 1.96 $\mathrm{ppm}$ and a triplet at $2.15 \mathrm{ppm}$ corresponding to the two methylene groups of the propionitrile moiety. Mass spectrum was complying with the structure of the compound.

\section{Pharmacology}

The $\mathrm{TD}_{50}$ of fluoxetine $(5.09 \mathrm{mM})$ and clomipramine $(2.00 \mathrm{mM})$ that potentiated 5-HTP-induced neurotoxicity were not statistically significant (Table 3). Similarly 15 new compounds out of 24 showed $\mathrm{TD}_{50}$ not significantly different from that of fluoxetine. This might indicate that they have antidepressant potency in this model similar to fluoxetine. From Table 3, it can also be seen that the remaining 9 compounds were less potent than fluoxetine. They have $\mathrm{TD}_{50}$ significantly higher than that of fluoxetine.

Clomipramine was twice as potent as fluoxetine to potentiate yohimbineinduced mortality. The 8 new compounds chosen to be tested in this model showed potency lower than that of clomipramine but were not significantly different (Table 4). 
Table 3: Effect of fluoxetine, clomipramine and newly synthesized compounds on 5-HTP-induced neurotoxicity in mice in vivo.

\begin{tabular}{||c|c|c||}
\hline Compound & $\mathrm{TD}_{50}(\mathrm{mM})$ & $95 \%$ C.L \\
\hline Fluoxetine & 5.09 & $2.72-9.51$ \\
\hline Clomipramine & 2.00 & $0.78-5.15$ \\
\hline $\mathbf{2 a}$ & $39.95^{\text {a }}$ & $10.89-146.48$ \\
\hline $\mathbf{2 b}$ & 4.69 & $2.12-10.39$ \\
\hline $\mathbf{2 c}$ & $49.36^{\mathrm{a}}$ & $14.83-164.29$ \\
\hline $\mathbf{3 a}$ & $16.58^{\text {a }}$ & $3.62-75.91$ \\
\hline $\mathbf{3 b}$ & 2.56 & $0.33-19.85$ \\
\hline $\mathbf{3 c}$ & $20.19^{\text {a }}$ & $9.49-42.95$ \\
\hline $\mathbf{3 d}$ & 4.04 & $1.56-10.49$ \\
\hline $\mathbf{3 e}$ & 4.69 & $2.12-10.39$ \\
\hline $\mathbf{3 f}$ & 8.15 & $2.89-22.95$ \\
\hline $\mathbf{3 g}$ & $18.65^{\text {a }}$ & $13.91-25.00$ \\
\hline $\mathbf{3 h}$ & 4.04 & $1.56-10.49$ \\
\hline $\mathbf{3 i}$ & 4.04 & $1.56-10.49$ \\
\hline $\mathbf{3 j}$ & $16.58^{\text {a }}$ & $3.62-75.91$ \\
\hline $\mathbf{3 k}$ & 8.15 & $2.89-22.95$ \\
\hline $\mathbf{3 l}$ & 5.43 & $2.83-10.41$ \\
\hline $\mathbf{3 m}$ & 4.04 & $1.56-10.49$ \\
\hline $\mathbf{4 a}$ & 15.26 & $7.95-29.29$ \\
\hline $\mathbf{4 b}$ & $16.57^{\text {a }}$ & $3.62-75.91$ \\
\hline $\mathbf{4 c}$ & 11.76 & $5.15-26.84$ \\
\hline $\mathbf{4 d}$ & $16.57^{\text {a }}$ & $3.62-75.91$ \\
\hline $\mathbf{5 a}$ & $20.19^{\mathrm{a}}$ & $9.49-42.95$ \\
\hline $\mathbf{5 b}$ & 4.69 & $2.12-10.39$ \\
\hline $\mathbf{5 c}$ & 5.43 & $2.83-10.41$ \\
\hline $\mathbf{8}$ & 5.43 & $2.83-10.41$ \\
\hline
\end{tabular}

$\mathrm{TD}_{50:}$ 5-HTP Median neurotoxic dose (mM).

95\% C.L.: 95\% confidence limit.

${ }^{a}$ Significantly different from respective Fluoxetine treated group at $\mathrm{p}<0.05$.

Statistical comparisons between groups were carried out by using Litchfield and Wilcoxon method ${ }^{16}$. 
Table 4: Effect of fluoxetine, clomipramine and some newly synthesized compounds on yohimbine-induced mortality.

\begin{tabular}{|c|c|c|}
\hline Compound & $\mathrm{LD}_{50}(\mathrm{mM})$ & $95 \%$ C.L \\
\hline Fluoxetine & $>12.90^{*}$ & - \\
\hline Clomipramine & 5.78 & $2.52-13.25$ \\
\hline $\mathbf{2 a}$ & 32.47 & $4.24-248.88$ \\
\hline $\mathbf{2 b}$ & 16.58 & $8.90-30.88$ \\
\hline $\mathbf{2 c}$ & 22.71 & $19.44-26.54$ \\
\hline $\mathbf{3 e}$ & 80.22 & $26.51-242.73$ \\
\hline $\mathbf{3 h}$ & 29.59 & $16.99-51.54$ \\
\hline $\mathbf{3 i}$ & 29.59 & $16.99-51.54$ \\
\hline $\mathbf{5 a}$ & 6.45 & $2.30-18.07$ \\
\hline $\mathbf{5 b}$ & 30.61 & $21.98-42.62$ \\
\hline
\end{tabular}

$\mathrm{YLD}_{50 \text { : }}$ Median yohimbine lethal dose $(\mathrm{mM})$.

95\% C.L.: 95\% confidence limit.

$* \mathrm{LD}_{50}$ for fluoxetine was not exactly calculated because a dose yohimbibe mortality curve could not be established experimentally.

Statistical comparisons between effect on 5-HTP treatment and yohimbine treatment were carried out by using Litchfield and Wilcoxon method (except for Fluoxetine tested by Fisher's exact test).

The 5-HT/NE selectivity of fluoxetine, clomipramine and selected 8 new compounds is shown in Table 5 and presented in Figure (1). The ratio for fluoxetine was $<0.39$ which was not calculated accurately in the present study because of the higher value of $\mathrm{TD}_{50}$ to potentiate yohimbine-induced mortality. It is expected, however, to be 0.1 from the literature $^{18}$. Clomipramine showed a ratio of 0.35 which was not significantly different from one. Of the 8 new compounds tested, $\mathbf{2 c}$ and 5a showed ratios of 2.17 and 3.13, respectively $(\mathrm{p}<0.05)$. Compounds $\mathbf{2 a}$ and $\mathbf{2 b}$ showed ratios of 1.23 and 0.28 which were not different than one. Compounds $\mathbf{2 c}$ and $\mathbf{5 a}$ might be considered as reuptake inhibitors of NE more than 5-HT.

The other 4 compounds, $\mathbf{3 e}, \mathbf{3 h}, \mathbf{3 i}$ and $\mathbf{5 b}$, showed ratios significantly lower than one. These compounds, therefore, can be considered as reuptake inhibitors of 5-HT more than NE. Of particular interest is compound 3e which showed the highest selectivity (ratio of 0.06 ). 
Table 5: 5-HT/NE selectivity of fluoxetine, clomipramine and new compounds.

\begin{tabular}{|c|c|c|c||}
\hline Compound & $\begin{array}{c}\mathrm{TD}_{50}(\mathrm{mM}) \\
(5-\mathrm{HT}) \\
\mathrm{X}\end{array}$ & $\begin{array}{c}\mathrm{LD}_{50}(\mathrm{mM}) \\
(\mathrm{NE}) \\
\mathrm{Y}\end{array}$ & $\begin{array}{c}\text { 5-HT/NE } \\
\text { Selectivity } \\
\mathrm{X} / \mathrm{Y}\end{array}$ \\
\hline Fluoxetine & 5.09 & $>12.90$ & $<0.39$ \\
\hline Clomipramine & 2.00 & 5.78 & 0.35 \\
\hline $\mathbf{2 a}$ & 39.95 & 32.47 & 1.23 \\
\hline $\mathbf{2 b}$ & 4.69 & 16.58 & 0.28 \\
\hline $\mathbf{2 c}$ & 49.36 & 22.71 & $2.17^{\mathrm{a}}$ \\
\hline $\mathbf{3 e}$ & 4.69 & 80.22 & $0.06^{\mathrm{a}}$ \\
\hline $\mathbf{3 h}$ & 4.04 & 29.59 & $0.14^{\mathrm{a}}$ \\
\hline $\mathbf{3 i}$ & 4.04 & 29.59 & $0.14^{\mathrm{a}}$ \\
\hline $\mathbf{5 a}$ & 20.19 & 6.45 & $3.13^{\mathrm{a}}$ \\
\hline $\mathbf{5 b}$ & 4.69 & 30.61 & $0.15^{\mathrm{a}}$ \\
\hline
\end{tabular}

a : Significantly different from that of fluoxetine at $\mathrm{p}<0.05$.

Statistical comparisons between effect on 5-HTP treatment and yohimbine treatment were carried out by using Litchfield and Wilcoxon ${ }^{16}$ (except for fluoxetine tested by Fischer's exact test)

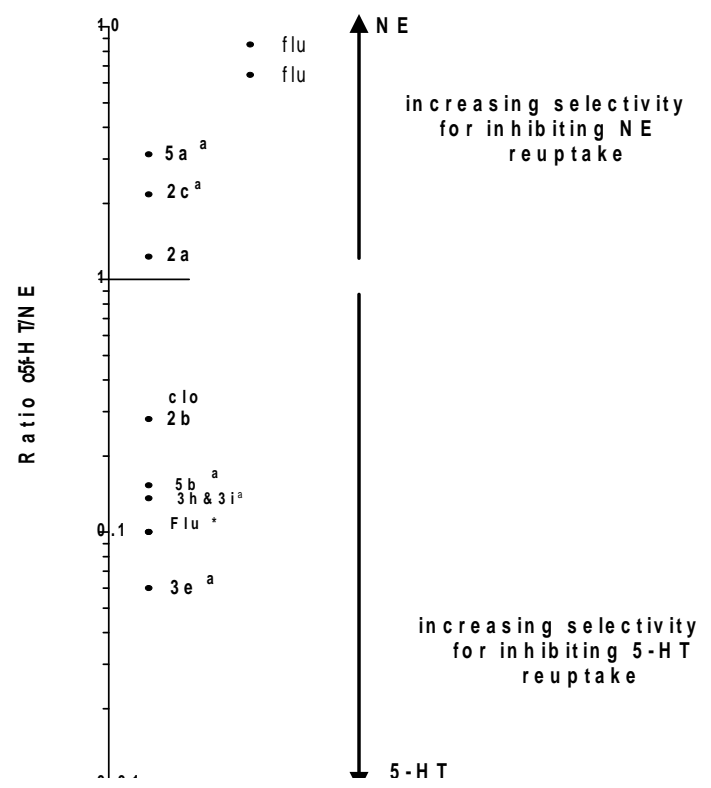

Fig. 1: Selectivity of Fluoxetine, Clomipramine (clo) and some of the newly synthesized compounds in inhibiting the teuptake of 5-HT and NE by using 5-HTP induced neurotoxicity and yohimbine induced mrtality as a ratio of $\mathrm{TD}_{50}$ in HTP model to that of yohimbine model.

a: significantly different from one at $\mathrm{p}<0.05$

* Fluoxetine rati from the literature 


\section{Structure-Activity Relationship (SAR)}

Antidepressant activity of the newly synthesized compounds showed that blockade of the secondary amino group of fluoxetine does not always decrease its activity or its selectivity. The urea derivative 2b retained its activity as 5-HTreuptake inhibitor while $\mathbf{2 c}$ showed a significant selectivity towards NE reuptake inhibition. Thiourea $\mathbf{3 a}$ decreases the activity of fluoxetine while increasing the length of the side chain or substitution with a cyclohexyl does not affect the activity of fluoxetine. Moreover, the majority of aromatic substituents of $\mathbf{3}$ did not change its activity. The phenyl derivative $\mathbf{3 e}$ showed potency as a (SRI) comparable to fluoxetine and at the same time, it demonstrated a high 5-HT/NE selectivity ratio. The cholinergic, histaminergic and adrenergic blockade of $\mathbf{3 e}$ were studied and found to display minimal effects as observed with fluoxetine ${ }^{19}$. Moreover $\mathbf{3 e}$ showed a safety margin $\left(\mathrm{LD}_{3} / \mathrm{ED}_{97}\right)$ equal to or even better than that of fluoxetine ${ }^{19}$. Acylation of fluoxetine 4a-d and 5a destroyed its activity as (SRI), while $\mathbf{5 b}$ and $\mathbf{5 c}$ retained (SRI) activity. 5a showed a significant NE/5-HT selectivity. 2-
Cyanoethyl derivative 8 showed a 5HT reuptake inhibition comparable to 5c. Calculated $\log P$ values of the new compounds, however, showed that all derivatization made to fluoxetine did not alter its lipophilicity as was hoped for (unpublished observation) (Table 6). Further studies are needed to explain why certain derivatization of fluoxetine decreased its potency as SRI, particularly in relation to peripheral hydrolysis with consequent less CNS availability.

The minimum energy conformer for fluoxetine (Figure 2) and $\mathbf{3 e}$ (Figure 3) was carried out. It was found that, as previously reported ${ }^{10}$, the propanamine chain in fluoxetine folds towards the trifuoromethylphenoxy ring to obtain the proper spatial orientation between the phenoxy ring and the basic nitrogen. Also, the methyl group at the nitrogen atom is proximal to the trifluoromethylphenoxy moiety. In compound $\mathbf{3 e}$, this orientation is retained, but the methyl group is lying remote (Figure 3). Therefore, it can be assumed that the minimum energy conformer is not necessarily, the most active conformer, at least with respect to the orientation of the methyl group in space. 
Table 6: Calculated $\log \mathrm{P}$ of the tested compounds.

\begin{tabular}{|c|c|c|c||}
\hline Compound & C log P & Compound & C log P \\
\hline Fluoxetine & 4.27 & $\mathbf{3 j}$ & 7.26 \\
\hline $\mathbf{2 a}$ & 5.37 & $\mathbf{3 k}$ & 7.26 \\
\hline $\mathbf{2 b}$ & 5.49 & $\mathbf{3 l}$ & 7.26 \\
\hline $\mathbf{2 c}$ & 6.05 & $\mathbf{3 m}$ & -------- \\
\hline $\mathbf{3 a}$ & 5.11 & $\mathbf{4 a}$ & 5.89 \\
\hline $\mathbf{3 b}$ & 5.45 & $\mathbf{4 b}$ & 5.82 \\
\hline $\mathbf{3 c}$ & 5.94 & $\mathbf{4 c}$ & 6.37 \\
\hline $\mathbf{3 d}$ & 6.66 & $\mathbf{4 d}$ & 5.06 \\
\hline $\mathbf{3 e}$ & 6.78 & $\mathbf{5 a}$ & 4.44 \\
\hline $\mathbf{3 f}$ & 7.33 & $\mathbf{5 b}$ & 4.94 \\
\hline $\mathbf{3 g}$ & 7.33 & $\mathbf{5 c}$ & 4.74 \\
\hline $\mathbf{3 h}$ & 7.60 & $\mathbf{8}$ & 4.68 \\
\hline $\mathbf{3 i}$ & 7.60 & & \\
\hline
\end{tabular}
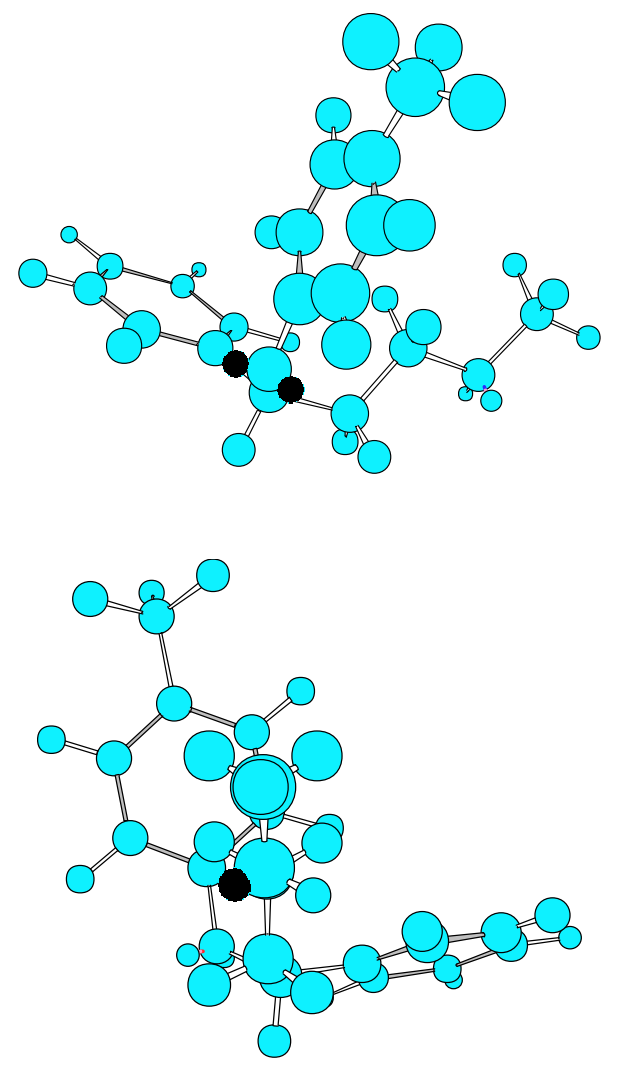

Fig. 2: 3D views of the minimum energy conformer of Fluxetine. 


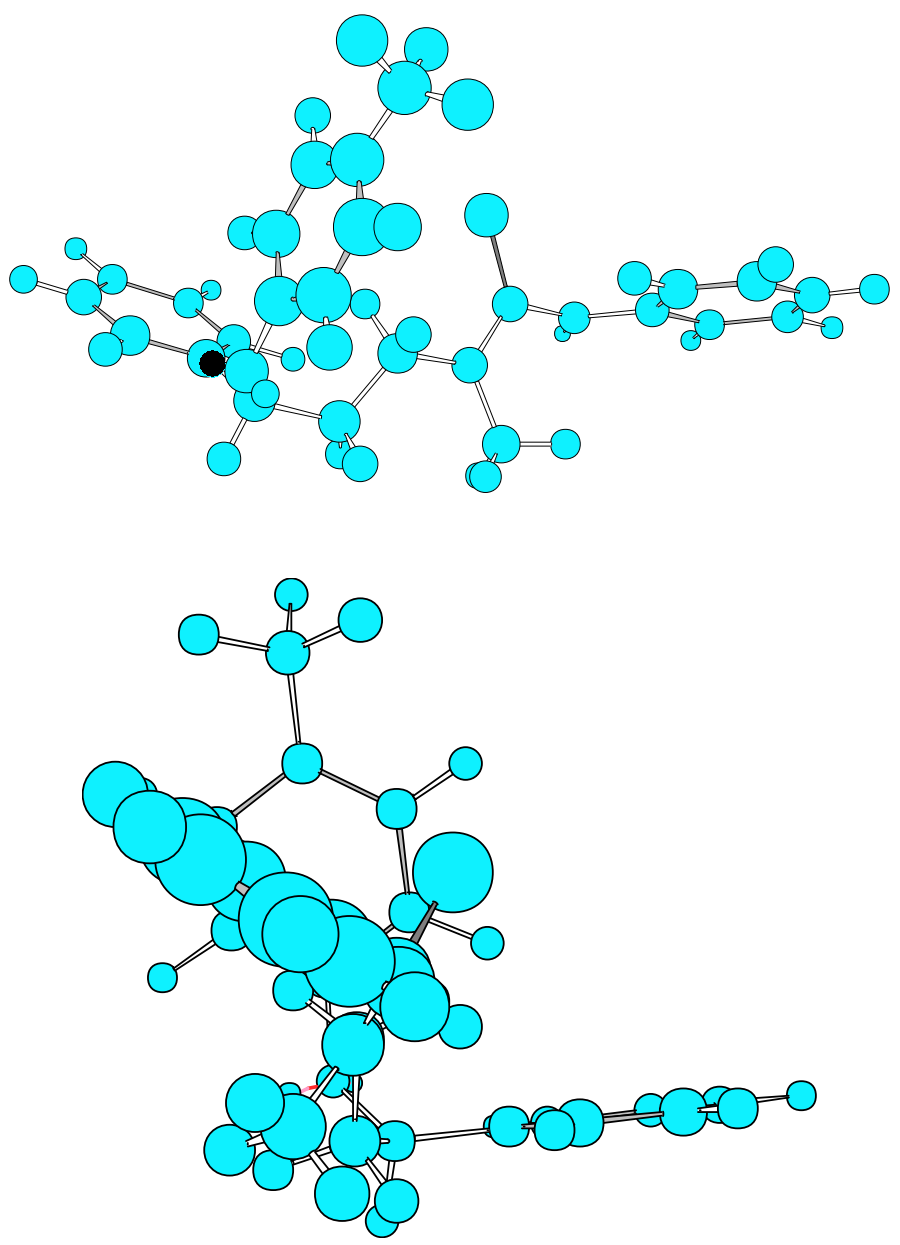

Fig. 3: 3D views of the minimum energy conformer of $\mathbf{3 e}$.

\section{REFERENCES}

1- A. Korolkovas, "Essentials of Medicinal Chemistry “, $2^{\text {nd }}$ Ed., A Wiley-Interscience publication Jhon Wiley \& Sons, 1988, pp. 307-328.
2- J. T. Kando, B. G. Welis, P. E. Hayes, "Depressive Disorders". In J. T. Dipiro, R. L. Talbert, G. C. Yee, G. P. Matzke, B. G. Welis, and L.M. Posey, "Pharmacotherapy, A Pathophysiologic Approach", $5^{\text {th }}$ Ed., 
McGraw-Hill Companies, Inc, 2002, pp. 1243-1264.

3- D. G. Waller, A. G. Renwick and K. Hillier, "Medical Pharmacology and Therapeutics", W.B. Saunders Ltd, 2001, pp. 251-262.

4- K. P. Bogeso and B. BangAnderson, "Dopamine and Serotonin Receptor and Transporter Ligands". In P. Krogsgaad-Larsen, T. Liljefors and U. Madsen, Textbook of Drug Design and Discovery, $3^{\text {rd }}$ Ed., Taylor and Francis, 2002, pp. 314-327.

5- S. M. Stahl, "Essential Psychopharmacology, Neuroscientific Basis and Practical Applications", $\quad 2^{\text {nd }} \quad$ Ed., Cambridge University Press, 2000, pp. 135-295

6- L. E. Hollister and N. Engl, J. Med., 299, 1106, 1168 (1978).

7- C. M. Spencer and M. I. Widdle, Drugs, 56, 405 (1998).

8- L. Iversen and R. A. Glennon, "Antidepressants" In Burger's Medicinal Chemistry and Drug Discovery, $6^{\text {th }}$ Ed., D. J. Abraham, Ed., John Wiley and Sons, Inc.; Canada 2003, Vol. 6, p. 483.

9- D. T. Wong, P. G. Therlkeld, K. L. Best and F. P. Bymaster, J. Phamacol. Exp. Ther., 222, 61 (1982)

10- R. W. Fuller, D. T. Wong and D. W. Robertson, Lilly Research Laboratories, Eli Lilly and Company, Lilly Corporate Center, Indianapolis, Indiana
46285, Medicinal Research Reviews, 11, 17 (1991).

11- P. Pratt, Affective Disorders In "Clinical Pharmacy and Therapeutics", $3^{\text {rd }}$ Ed., R. walker and C. Edwards, Eds., Churchill Livingstone, London, 2003, p. 439.

12- D. W. Robertson, N. D. Jones, J. K. Swartzendruber, K. S. Yang and D. T. Wong, J. Med. Chem. 31, 185 (1988).

13- L. Orus, S. Perez- Silanes, A-M. Oficialdegui, J. MartinezEsparaza, J-C. Del Castillo, M. Mourelle, T. Langer, S. Guccione, G. Donzella, E. M. Krovat, K. Poptodorov, B. Lasheras, S. Ballaz, I. Hervias, R. Tordera, J. Del Rio and A. Monge, J. Med. Chem. 45, 4128 (2002).

14- Z. Crnic and S. Kirin, EP 617, 006(Cl.C07C 213/06).

15- S. J. Corne, R. W. Pickering and B. T. Warner, Br. J. Pharmacol., 20, 106 (1963).

16- G. T. Litchfield and S. Wilcoxon, J. Pharmacol. Exp. Ther., 96, 99 (1949).

17- R. M. Quinton, Br. J. Pharmacol., 21, 51 (1963).

18- C. Rubat, P. Coudert, P. Bastide and P. Tronche, J. of Pharmacy and Pharmacology, 47, 162 (1995).

19- G. E. Abdel-Hamid, M.Sc. Thesis, Faculty of Pharmacy, Helwan University (2005). 